\title{
Yeni Medyada Kaynağa Güven ve Kanaat Önderleri
}

- Nurettin Güz

Prof. Dr. Hac1 Bayram Veli

Üniversitesi

nurettinguz@gmail.com

ORCID ID:0000-0002-20385652

- Zeynep Gazali Demirtaş

Arş. Gör. Dr. Süleyman

Demirel Üniversitesi

zeynepgazali@gmail.com

ORCID ID: 0000-0003-3460-

2977

\section{ÖZET}

Genel olarak teknoloji ama özellikle iletişim teknolojilerindeki gelişmeler medya kuruluşlarının etkileri ile ilgili tartışmaların da sorgulanmasını gündeme getirmiştir. Medya imkânlarının sinırlı olduğu dönemlerde kanaat önderleri olarak adlandirılan kişilerin, seçmenlerin siyasal tercihleri üzerinde medyadan daha etkili olduğu tezi, iletişim etki araştırmalarında önemli bir yer tutmaktadır. Ancak günümüzde internet tabanl bilgi ve iletişim, kaynak ve ağlarının gelişmesine paralel olarak gelişen yeni medya araçlart, bireyin medyaya ulaşımın kolaylaştırı farklı araçlardan haber ve bilgi alma imkânını genişletmekte ve bununla birlikte bireylerin bilgi kirliliği ile karşılaşma riskini de ortaya çıkarmaktadır. Bu çalışmanın konusunu yeni medya çağında artan siyasi bilgi kaynaklarına duyulan güven ve kanaat önderleri oluşturmaktadır. Çalışmada yeni medya ortamlarında siyasi bilgi kaynakların belirlenmek, yeni medya ortamlarında kanaat önderlerinin etkisini incelenmek, siyasi bilgi kaynaklarına duyulan güven ve siyasi bilgi kaynaklarının oy tercihleri üzerindeki etkisini belirlemek amaçlanmıştır. Çalışma verileri siyasal parti ve adaylar, kampanya yürütücüleri, medya ve akademisyenler kadar kamuoyunun bu konudaki bilgi ihtiyacını karşılayacă̆ için önemlidir. Çalışmanın amacına yönelik olarak 16 Nisan 2017 Referandumu öncesinde Ankara ilinde 400 kişi ile yüz yüze görüsme yöntemiyle bir alan araştırması gerçekleştirilmiştir. Yapılan alan araştırması sonucunda, kitle iletiş̧im araçlarının gelişmesi ve yayginlaşmasina rağmen bireylerin siyasal bilgi kaynă̆l olarak öncelikle yakın çevrelerine güven duyup, yakın çevrelerinden etkilendikleri belirlenmiştir. Ek olarak Türkiye'de kanaat önderleri varlığın sürdürmekle birlikte eğitim düzeylerinin artmasıyla kişilerin sosyal medyadan ve diğer yeni medya araçlarından faydalandıkları tespit edilmiştir.

Anahtar Sözcükler: Yeni medya, Sosyal medya, Kanaat önderleri, Kamuoyu önderleri, Medya güven, Siyasal İletişim 


\section{Trust the Source in New Media and Opinion Leaders}

\section{- Nurettin Güz}

Prof. Dr. Hacı Bayram Veli University nurettinguz@gmail.com ORCID ID:0000-0002-20385652

\section{- Zeynep Gazali} Demirtaş

Res. Ass. Dr. Süleyman Demirel University zeynepgazali@gmail.com ORCID ID: 0000-0003-34602977

\begin{abstract}
Advances in communication technologies have led to questioning of the debate about the effects of media organizations. The thesis that opinion leaders are more effective than the media on voters ' political preferences during periods when media tools are more limited occupies an important place in Communication Impact Research. But today, New Media tools facilitate a person's access to the media and expand the opportunity to receive news and information from different tools. This increases the risk that individuals will face information pollution. The subject of this study is the confidence and opinion leaders in the growing sources of political information in the new media age. The aim of the study was to determine the sources of political information in new media environments, to examine the influence of opinion leaders in new media environments, to determine the confidence in political information sources and the influence of political information sources on voting preferences. for this purpose, a face-to-face survey was conducted with 400 people in Ankara province before the 16 April referendum election. As a result of the research, it was found that despite the development and spread of mass media, individuals trust their immediate environment as a source of political information and are influenced by their immediate environment. In addition, although opinion leaders continue to exist in Turkey, it has been found that people are taking advantage of social media and other New Media tools as educational thinking increases.
\end{abstract}

Keywords: New Media, Opinion Leaders, Social Media, Media trust, Political Communication 


\section{GİRIȘ}

Seçmenlerin siyasal karar alma sürecinde hangi faktörlerin etkili olduğu, parti ve aday tercihlerini neye göre belirledikleri, siyasiler, kampanya yürütücüleri ve medya başta olmak üzere hemen herkesin ilgisini çeken bir konu olmuş, bu çerçevede kanaat önderlerine özel bir önem atfedilmiştir. İletişim çalışmalarında güçlü etkilerden sınırlı etkilere evrilen süreç ve günümüze uzanan dönemlerde kanaat önderleri daima iletişim etki araştırmalarının merkezinde yer almıştır. Kanaat önderlerinin yoğun ve etkin olduğu ülkelerde medyanın etkilerinin sınırlı, özellikle seçmenlerin parti ve oy tercihlerinde medya yerine kişiler arası iletişimin etkili olduğu araştırmalarla ortaya konmuştur. Yüz yüze iletişim başta olmak üzere kişiler arası iletişim ve etkileşimde karar alma sürecine doğrudan etki eden kanaat önderleri, siyaset başta olmak üzere farklı konulardaki karar alma sürecinin belirleyici ve etkileyicisi olabilmektedir. Tıpkı diğer vatandaşlar gibi kendileri de medyayı aktif olarak kullanan kanaat önderleri medya mesajlarını kendi yargı ve yorum süzgecinden geçirerek diğer bireylere aktarmaktadır.

Kanaat önderleri kavramı medya araçlarının sınırlı, her kesiminin medya araçlarına kolaylıkla ulaşamadığı, kişiler arası ilişkilerin kuvvetli olduğu bir dönemde büyük ilgi görmüştür. Günümüzde yaşanan teknolojik gelişmeler, internetin insanlığın hizmetine sunulması bilgi arama ve alma şekillerini değiştirmiştir. Bu değişikliklerle beraber sosyal ilişkiler sayısal kodların oluşturduğu ağlara taşınmış, bu sayede bireyler birbirleriyle ve tanımadıkları kişilerle, ünlülerden, siyasilere kadar birçok kişiye daha hızlı ve kolay bir şekilde ulaşır duruma gelmiştir. Yapılan araştırmalar internetin geleneksel haber kaynaklarına ek olarak politika (Olkun, Yüksel, \& Akdemir, 2018, s. 999) ve toplum hayatına katılımı artıran bir öğrenme aracı olduğunu vurgulamaktadır (Shah, Cho, Eveland, \& Kwak, 2005, s. 564; Shah, Schmierbach, Hawkins, Espino, \& Donavan, 2005, s. 980; Bimber, 1998). Bununla birlikte iletişim teknolojisinde yaşanan bu gelişmeler kanaat önderliği kavramını yeniden gündeme getirmiştir (Wang, 2017, s. 2519) Yapılan araştırmalar geleneksel medya araçlarının artması ve ulaşılabilirliğine rağmen sosyal medya aracılığıyla kişiler arası ilişkilerin (Peng, Liu, Wu, \& Liu, 2016, s. 997) ve politik görüşün oluşumunu (Huckfeldt, Johnson, \& Sprague, 2004, s. 44) şekillendirdiği tezine kanıtlar sunmaktadır (Huckfeldt \& Sprague, 1995, s. 158) Diğer taraftan internet insanlara bilgiye erişim ve sivil faaliyetlerde bulunmalarında birçok kolaylık sunsa da (Shah, Cho, Eveland, \& Kwak, 2005, s. 551)yapılan çalışmalar internet kullanıcılarının yeni 
medya ortamındaki aşırı bilgi kirliği sorunlarından etkilendiğini göstermektedir. Bilgi kirliliği sorunu beraberinde haber ve bilgi kaynağına güven konusunu gündeme getirmektedir.

Bu çalışmanın konusunu yeni medyada siyasi bilgi kaynaklarına güven ve kanaat önderleri oluşturmaktadır. Çalışmanın amacı yeni medya ortamlarında siyasi bilgi kaynaklarının belirlenmesi, kaynağa duyulan güven ve siyasi bilgi kaynaklarından hangilerinin oy tercihlerinde etkili olduğunun belirlemesi oluşturmaktadır. Çalışmanın amacına yönelik olarak 16 Nisan 2017 Referandumu öncesinde Ankara ilinde 400 kişis ile yüz yüze görüşme yöntemiyle bir alan araştırması gerçekleştirilmiştir.

Yeni medya araçları kişilere bilgiye ulaşmada birçok kolaylık sağlasa da yeni medya ortamlarında birçok provokatif veya dezenformasyonel içerik ile karşılaşılması olasıdır. $\mathrm{Bu}$ bilgi fazlalı̆̆ 1 karmaşasında kişiler hangi kaynaklara güveneceğine dair belirsizlik yaşayabilmektedir. Seçmenlerin hangi siyasi bilgi kaynağına daha çok güvendiklerinin tespit edilmesi, siyasi davranışı belirleyecek olan medya araçlarının belirlenmesi açısından da önemli bir yer tutmaktadır. Bu çalışma, yeni medya araçlarının bilgi alma alışkanlıklarını nasıl etkilediği, seçmenlerin seçim kampanyaları hakkında en çok hangi kanallardan bilgi aldıkları ve etkilendikleri, hangi kanallara daha çok güvendiklerinin ortaya konulması açısından önemlidir. Diğer taraftan Türkiye'nin toplum yapısı ve toplumsal ilişkileri ABD ve Batı ülkelerinden farklılık göstermektedir. Bu durum dikkate alınarak çalışmada elde edilen bulgular Türkiye’nin kendine özgü dinamikleri göz önüne alınarak yorumlanmıştır.

Araştırmada ilk olarak günümüzdeki siyasi bilgi kaynakları ve kanaat önderlerinin siyasi bilgi almadaki rolüne yer verilmiş, sonrasında yeni medya ortamlarında siyasi bilgi kaynaklarına duyulan güven ve kişiler arası ilişkilerin oy tercihlerine etkisi tartışılmıştır. Son bölümde ise 16 Nisan Referandumu öncesinde alan araştırması ile toplanan verilerle yapılan analiz sonucunda seçmenlerin en çok hangi siyasi bilgi kaynaklarını kullandıkları, hangi kaynaklara güvendikleri ve hangi kaynaklardan etkilendiklerine yer verilmiştir.

\section{SIYYASİ BILLGİ KAYNAKLARI VE KANAAT ÖNDERLERİ}

Seçmen davranışları her zaman siyasilerin ve kampanya yürütücülerinin ilgisini çeken, merak uyandıran konular arasında yer almıştır. İletişim araştırmalarının öncü çalışmalarında kişilerin oy tercihlerinde medyanın etkin rol oynadığı kabul edilmekte, seçmenlerin medya etkileri karşısında pasif izleyiciler oldukları düşünülmekteydi. Sonrasında Lazarfeld ve 
arkadaşları tarafından yapılan çalışmalarda medya etkilerinin abartıldığı ortaya konularak seçmenlerin oy tercihlerinde kişiler arası etkinin rolüne dikkat çekildi. Lazarfeld ve arkadaşları yaptıkları ilk çalışmalarda tüm seçmenlerin medyayı aktif olarak kullanmadıklarını ve medyadan etkilenmediklerini buldular. Kişiler oy tercihlerini belirlemede medyanın aksine, kanaat önderleri olarak tanımlanan kişilerden etkilenmekteydi. Kanaat önderleri medyayı daha fazla kullanmakta, siyasi konulara daha fazla ilgi duymakta ve siyasetle ilgili sıklıkla konuşma başlatan kişilerden oluşmaktaydı. (Berelson, Gaudet, \& Lazarfeld, 1944, s. 49) Bununla birlikte Lazarsfeld ve arkadaşları, kanaat önderleri kavramının otoriter ya da karizmatik bir liderlik biçimi olmadığını, daha çok günlük ilişkilerde ortaya çıkan görünmez bir liderlik biçimi olduğunu ifade ettiler. (Katz \& Lazarfeld, 1955, s. 33) Sonraki yıllarda konu ile ilgili çok sayıda çalışma yapıldı (Demirtaş, 2019a, s. 14-62)

Kanaat önderleri kavramının ortaya atıldığ1 dönemde televizyon henüz yaygınlaşmamıştı. Radyo ve gazeteler ana medya organları olarak hizmet vermekteydi. Medya araçlarının sınırlı olduğu bu dönemde kanaat önderleri olarak isimlendirilen bu kişiler seçmenlerin oy tercihlerinde belirleyici olmaktaydı. Kitle iletişim araçlarının daha az gelişmiş olduğu dönemlerde siyasi konuşma ve kişiler arası ilişkiler siyasi bilgi edinme açısından önemli bir yer tutmaktaydı. Ancak 20. yüzyılın başında telsiz ardından radyo ve televizyon yayıncılı̆̆ı, uydu hizmetleri ve cep telefonu ile devam eden sonrasında 20. yüzyılın son çeyreğinde ortaya çıkan internetle birlikte kitle iletişim teknolojileri muazzam bir şekilde gelişti. Bilgisayar temelli iletişimde yaşanan gelişmelerle kitle iletişimin internet ağıyla bilgisayar ağında birleşmesi, metin, ses, resim ve hareketli görüntü gibi enformasyonun birçok biçimin bu ağ üzerinden gönderilip alınabilmesini mümkün hale getirdi. İnternet teknolojisi sayesinde dünyanın bir ucunda yaşanan olaylara anında ulaşabilmenin yanı sıra o olaylara interaktif bir şekilde katılmak da mümkün oldu (Dijk, 2018, s. 87). İnternet kullanıcıları interneti benzer ilgi alanları ve değerlere sahip başkalarıyla tanışmak için, kişiler arası iletişimde kullanır duruma geldi (Bargh \& McKenna, 2004, s. 53). Sosyal medya kullanımının giderek artması ciddi bir iletişim ve etkileşim ortamının oluşmasını sağladı. Özellikle Facebook, Twitter gibi kullanıcı sayıları yüz milyonları bulan uygulamalar, kullanıcılara bilgi ve fikir paylaşma, inançlar, düşünceler etrafında birleşme gibi faaliyetlerde birbirleriyle iş birliği yapma firsatı verirken geniş grupları ortak hareket edebilir duruma getirdi (Shirky, 2010, s. 97). 
Bununla birlikte sosyal medya bir bilgilendirme kaynağı haline geldi (Bimber, 1998, s. 138-140; Kushin \& Yamamoto, 2010, s. 114) Kullanıcılar geleneksel medyanın yanında sosyal medyadan haber ve politik bilgilere erişebilir oldu. ABD'de yapılan bir araştırma, sosyal medya sitelerinin Amerikalılar için bir haber kaynağı olarak gazeteleri aştığını gösterdi (Shearer, 2018). Oxford Üniversitesi Reuters Gazetecilik Çalışma Enstitüsü, 2016 yılında hazırladığ1 Dijital Haber Raporunda, Türkiye'de internet kullanıcılarının \%73'ünün sosyal medyayı bir haber kaynağ1 olarak gördüğünü ortaya koydu (Newman, Fletcher, Levy, \& Nielsen, 2016). Türkiye'de yapılan araştırmalarda haftalık en sık kullanılan iletişim aracı olarak internet ve sosyal medya yer aldı (Balc1, Damlapınar, Pınarbaş1, \& Astam, 2016, s. 123-124; Gündüz \& Pembecioğlu, 2013, s. 329).

Yeni medya araçlarından sosyal medyanın bilgi kaynakları arasında yer alması, sosyal medyayı çalışmamız açısından önemli kılmaktadır. Sosyal medya, kullanıcılara verdiği doğru ya da yanlış bilgilerle faaliyetlere yön veren, fikirlere anlam katan, tutum ve davranışları değiştiren bir ortam olarak karşımıza çıkmaktadır (Büyükaslan \& Kınık, 2017, s. 255). Diğer taraftan yaşanan bu teknolojik gelişmeler yalnızca iletişim teknolojilerini değil toplumsal, örgütsel iletişimi de değiştirmektedir. Gelişen iletişim araçlarıyla birlikte yeni bir toplum modelini ortaya çıkarmakta ve bu toplum modelinde ilişkiler yüz yüze iletişim yerine sosyal ağlar üzerinden gerçekleştirilmektedir (Dijk, 2018, s. 72).

Lazarfeld ve arkadaşları tarafından ortaya atılan öncü çalışmalarda, medyanın kişilerin oy tercihinde sınırlı etkileri bulunmakta kanaat önderleri seçmenler ve medya arasında köprü görevi görmekteydi. Günümüzün iletişim ortamlarında kişilerin bilgiye ulaşması kolaylaşmış, bilgiye ulaşma kaynakları çoğalmıştır. Bununla birlikte geçmişte ön planda olan birincil yakın yüz yüze iletişim yerini, bugün kolay ulaşılmasına ve kalabalık grupların bir araya gelmesine izin veren sosyal mecralardaki farklı ideoloji ve görüşte olan, tercihte bulunanlarla gerçekleştirilen uzak ikincil ilişkilere bırakmıştır. Medyanın yaygınlaştığı 20. yüzyılın ikinci yarısında kanaat önderleri toplumların eğitim ve kültür düzeyi, sosyo-ekonomik konumu, toplumsal örgütlenme biçimi, bireysel ve toplumsal ilişkilerin yapısına göre kimi toplumlarda konumunu muhafaza etmiştir. Kavramın yeni teknolojiler ve yeni medya ile birlikte nasıl bir konuma evrildiğine ilişkin araştırmalar da yapılmakta (Hwang, 2015, s. 258-262), çalışmalarda kanaat önderlerinin yeni medyada iletişim ortamlarının yapılandırma sıklığına vurgu yapılması istenmektedir (Schäfer \& Taddicken, 2015) 
Türkiye'de yapılan çalışmalarda da kanaat önderleri ile ilgi çekici sonuçlara ulaşılmıştır. Yapılan çalışmalarda kimi zaman sosyal ağlarda fenomen olanların kanaat önderi konumunu üslendiklerine vurgu yapılırken, (Aslan \& Ünlü, 2016) spor bilimleri eğitim alan üniversite öğrencileri üzerinde yapılan bir çalışmada (Güz \& Yeğen, 2019) bu öğrencilerin futbol konusunda kanaat önderi konumunu üstlendikleri ortaya çıkarılmıştır. Yine 2019 yılında yapılan alan araştırmasına dayalı başka çalışmalarda, yeni medyada kanaat önderlerinin varlığını sürdürdüğü (Güz \& Demirtaş, 2019, s. 12-15; Demirtaş, 2019a; Demirtaş, 2019b, s. 201) ortaya konmuştur.

Son dönem iletişim araştırmalarında kanaat önderlerinin konumuna ilişkin çalışmalar önemini korurken demokrasinin gelişmesi ve yaygınlaşmasına paralel olarak seçmen davranışlarına etki eden faktörler ve bunlar içerisinde kanaat önderlerinin rolünün belirlenmesi ayrı bir çalışma alanı olarak karşımıza çıkmaktadır. Siyasal bilgi alma, kanaat ve tutum oluşturmada kanaat önderlerinin ön plana çıkması siyasiler, siyasal kampanya yürütücüleri, medya ve siyasal sürecin içerisinde olanların çalışmalarını buna göre düzenlemelerini zorunlu k1lacaktır.

\section{YENI MEDYA VE KAYNAĞA GÜVEN}

Bilgisayarlara ve iletişim araçlarına özgü yapıları barındıran, iki yönlü olan, bilgisayar ve enformasyon teknolojileri üzerinden bilgiyi dijital formda taşıyıp ileten araçlar olarak tanımlanan yeni medya, (Güz, 2018, s. 15) kavram olarak teknolojik gelişmelerde en son olana gönderme yapmaktadır. Dijital temsil, modülerlik, otomasyon, değişkenlik ve kod çevrimi olmak üzere beş temel özelliği bulunan yeni medya; (Manovich, 2001, s. 27-48) alıcı ve vericinin eş zamanlı iletişim kurması, etkileşim içerisinde bulunması, (McMillan, 2006, s. 205) kullanıcı sayısının çokluğuna rağmen her bireyin özel mesaj değişimi yapabilmesi, mesaj gönderme ve almayı farklı zamanlara ve gerçek zamanda ( Castells \& Ince, 2006, s. 26-27) yayma imkanı vermesi (Geray, 2003, s. 27-48) sebebiyle farklıdır. Farklı verilerin kombinasyonunu sağlaması, verileri değişik biçimlerde sunabilmesi, enformasyonun toplanmas1, yayılması ve depolanması (Pavlik, 1998, s. 80) özelliklerine de sahip olması yeni medyayı güçlü kılmaktadır. Yeni gelişen iletişim teknolojilerinin, geleneksel medyanın aksine, çevrimiçi bir iletişim ortamı oluşturması, her kullanıcıyı bir yayıncıya dönüştürmesi, ek kaynak ve bilgiler sunması, gerçek zamanlı ve güncellenmiş bilgiler vermesi, çevrimiçi sohbet 
ortamlarında yüksek katılım sağlaması (Tailor \& Perry, 2005, s. 212) yeni medyayı konumuz açısından önemli kılmaktadır.

Yeni medya ile birlikte haber alma ve tartışma ortamları büyük bir değişim geçirmiştir. Geleneksel medyadan, yeni medyaya giden süreçte haber; haber merkezlerinin örgütlenme biçimi, haber kaynakları, haber içeriği ve içeriğe ulaşma, haberin sunumu, eşik bekçileri, etik ilkeler ve haberde başarı açısından değişikliğe uğramıştır (Güz, 2018, s. 20-27). Radyo, televizyon, gazete, dergi vb gibi araçların oluşturduğu geleneksel medyadan farklı olarak yeni medya ile birlikte onun bir parçası olarak devreye giren sosyal ağlar aracılığı ile haber ve bilginin yayılım düzeyi ve oranı çok artmıştır. Ancak gelişen siyasi bilgi arama kanalları, seçmenlerin hangi bilgi kaynaklarına güvenmesi gerektiğini zorlaştırabilmektedir. İnternet, kişilere faydalı bilgilere erişmeleri için birçok farklı kanal sunsa da (Shah, Cho, Eveland, \& Kwak, 2005, s. 551) internet kullanıcıların yeni medya ortamındaki aşırı bilgi kirliliği sorunlarından etkilenebilmektedir. Sosyal medyada hedef saptırıcı provokatif veya dezenformasyonel birçok içerik ile karşılaşılması olasıdır. Bu bilgi kirliği karmaşasında kişiler hangi kaynaklara güveneceği konusunda belirsizlik yaşayabilmektedir. Medya içeriğinden etkilenmenin söz konusu olabilmesi için kişilerin kaynağı güvenilir bulmalarının büyük önemi bulunmaktadır (Güz, 2005, s. 57; Stroud \& Lee, 2013, s. 85).

Yeni iletişim teknolojileriyle birlikte kişiler haber ve bilgileri sanal ortamlarda tartışabilir, yeniden yorumlayabilir ve yayınlayabilir duruma gelmiştir. Milyonlarca sosyal medya kullanıcısının aynı zamanda içerik üreticisi olması, dezenformasyonu da birlikte getirmekte, kullanıcıların muazzam sayıda içeriği nasıl değerlendireceği konusunda yeterince bilgi sahibi olmaları kimi zaman mümkün olamamaktadır (Lin, Li, Deng, \& Lee, 2013, s. 160168) Bu durum kanaat önderlerinin yeni iletişim teknolojilerinin geliştiği dönemde varlıklarını sürdürebilmeleri açısından sosyal ağları önemli bir platform olarak karşımıza çıkarmaktadır. İnsanlar çok fazla medya seçeneklerine maruz kaldıklarında neye karar vereceklerini seçmede kendilerine sosyal ağları aracılığıyla ulaşan öneriler etkili olabilmektedir. (Mutz \& Young, 2011, s. 1038). Bununla birlikte birçok insan, blogları geleneksel kaynaklardan daha güvenilir olarak değerlendirmektedir (Johnson \& Kaye, 2004, s. 633-634). Geleneksel haber kaynağından alınan bir haber sosyal ağlardan bir arkadaş ya da uzman olarak gördükleri bir kişi aracılığıyla paylaşılıyorsa güvenilir olarak algılanabilmektedir (Yıldızgörür, 2018). 
Diğer taraftan son yıllarda, internet dünyada çok hızlı bir şekilde gelişmiş ve yaygınlaşmıştır. Dolayısıyla internete duyulan güven bireylerin yaş, eğitim, meslek gibi demografik özelliklerinden etkilenebilmektedir. Bununla birlikte ilk medya etki araştırmaları ABD ve Batı kaynaklı çalışmalardır. Yapılan araştırmalarda da kanaat önderlerinin kültürlerarası farklılıklar gösterebileceğine dikkat çekilmiştir (Weiman, 1994, s. 93-93).

Literatürde kanaat önderleri iş arkadaşları, komşu aile arasında olan yakın ilişkilerle görülmez liderlik özellikleriyle tanımlanırken, Türkiye örneğinde kanaat önderliği kavramı daha karmaşık bir içeriğe sahiptir. Türkiye'de kanaat önderi kavramı, medyadan, pazarlamaya, ekonomiden, din alanına kadar geniş bir yelpazeyi kapsamaktadır. Türkiye'de kanaat önderleri kavramı birincil yakın ilişkilerden ziyade daha çok ikincil yakın ilişkiler akademisyenler, muhtarlar, aşiret liderleri vb ilişkiler için kullanılmaktadır (Ulutaş, 2015).

Yeni iletişim teknolojileri medya kuruluşları ve toplumsal ilişkileri farklılaştırdığı gibi medyanın etkileri ile ilgili bulguların da yeniden gözden geçirilmesini zorunlu kılmaktadır. Toplumsal örgütlenme biçimleri, medya kaynaklarına duyulan güven, kişiler arası ilişkiler toplumdaki kanaat önderlerinin rolü, kişilerin sosyo-demografik özellikleri, siyasi kaynaklara olan ilgisi, bilgi akışını etkileyen faktörler arasında yer almaktadır. Bu sebeple kanaat önderleri kavramını gelişen iletişim olanakları ve toplumsal örgütlenme ve toplumsal ilişkiler göz önünde bulundurularak Türkiye örneğinde yeniden düşünmek gerekmektedir.

\section{YENI MEDYADA KAYNAĞA GÜVEN ÜZERİNE BİR ARAŞTIRMA}

Makalenin bu bölümünde, yapılan alan araştırma verilerine ve analizine yer verilmiştir.

\subsection{Araştırmanın Problem Cümlesi}

1. İletişim araçlarının daha sınırlı olduğu dönemlerde siyasi tercihlerde etkin rol oynayan kanaat önderleri, günümüzün iletişim ortamlarında kişilerin siyasi tercihleri nasıl etkilemektedir.

2. Seçmeler yeni medya çağında sosyo-demografik sosyo- ekonomik özelliklerine göre hangi siyasi bilgi kaynaklarına daha çok güvenip bilgi almaktadır? 


\subsection{Araştırmanın Planlanması ve Örneklem}

Bilim ve teknolojide yaşanan gelişmelerle birlikte bilgi arama ve alma şekilleri değişmiştir. İlk dönemlerde medya imkânlarının daha sınırlı olduğu yıllarda medya ile seçmenler arasında köprü görevi gören kanaat önderleri, insanların siyasal tercihlerinde etkili olurken, günümüzde gelişen iletişim teknolojileri seçmenler başta olmak üzere herkese aynı anda birçok kanaldan farklı bilgiye ulaşabilme firsatı vermektedir. Gelişen teknoloji farklı kanallardan bilgiye ulaşma imkânı verirken bilgi kirliliği sorununu da beraberinde getirmektedir. Bu çalışmanın amacı doğrultusunda seçmenlerin yeni medya ortamlarında tercih ettikleri bilgi kaynaklarının belirlenmesi ve bu kaynaklara duyulan güven ile siyasi bilgi kaynakların oy tercihleri üzerindeki etki düzeyini belirlemek üzere bir alan araştırması gerçekleştirilmiştir. Yapılan araştırma çerçevesinde siyasal tercihlerde medya ve kişilerarası ilişkilerin ağırlığı da belirlenmeye çalışılmıştır.

Kanaat önderleri konusu ile ilgili ilk alan araştırmaları ABD'de yapılırken, kanaat önderleri kavramının Türkiye örneğinde farklı çağrışımları bulunmaktadır. Bu karışıklığın önüne geçmek için, planlanan alan araştırmasında bireylerin etkilendikleri anne, baba, arkadaş vb. birincil yakın ilişkilerde bulunulan kişiler yakın çevre, dernek vakıf başkanı, muhtar, öğretmen sözü geçen sevilen kişiler kanaat önderleri olarak değerlendirilmiştir. Araştırmaya katılanlara geleneksel medya, internet haber siteleri, sosyal medya (Facebook, Twitter, blog ve forumlar), yakın çevre ve kanaat önderlerinden bilgi alma düzeyleri, değerli buldukları bilgi kaynakları, siyasal tercihlerinde etkilendikleri bilgi kaynakları ile ilgili sorular yöneltilmiştir.

Araştırma verilerinin derlenmesi ile ilgili örneklem Ankara ilinden derlenmiştir. Ankara'nın coğrafi konumu, sosyo-demografik, sosyo-ekonomik ve sosyo-kültürel özellikleriyle Türkiye'yi temsil edebileceği düşünülmüştür. Ankara'daki ilçelerin nüfus ağırlıkları dikkate alınarak farklı ilçelerden tesadüfi örneklem yöntemiyle belirlenen 400 katılımcıdan veriler derlenmiştir. Tamamı üniversite öğrencilerinden oluşan anketörler tarafından 16 Nisan 2017 Referandumundan 15 gün önce katılımcılarla yüz yüze görüşülerek sorulara cevaplar alınmıştır.

Araştırma verilerinin derlenmesi özellikle 16 Nisan Referandumu öncesinde yapılmıştır. Bunun iki amacı vardır: Birincisi bu çalışma açısından önemli olan haber kaynaklarına güvenin bu dönemde toplumun medyaya duyacağı güvenin artması sebebiyle 
verilerin sağl1klı alınabileceği düşüncesidir. Kişilerin tutum değiştirmesinde kaynak güvenilirliğinin merkezi bir role sahip olması (Ladd, 2010, s. 32) sebebiyle haber kaynaklarına duyulan güven, politik davranışı da etkileyebilmektedir. İkincisi, siyasal etkilenme ve tutum oluşturmanın en yoğun sürecinin seçim ve referandum kampanyalarının olması sebebiyle referandum sürecinin iyi bir veri derleme süreci olacağı düşünülmüştür. Bu çalışma için, Gazi Üniversitesi Etik Kurulundan 77082166-/302.08.01 say1lı ve 03.03.2017 tarihli "Etik Kurul Onayı" alınmıştır.

Araştırmanın örneklemine bakıldığında toplam 400 katılımcının \% 43,8'ini kadınların, \% 56,3’ünü ise erkeklerin oluşturduğu gözlenmektedir. Yine katılımcıların; \% 33’ü 18-25, \% 27,5'i 26-35, \% 19,3’ü 36-45, \% 20,3’ü 46-65 ve 65 üstü yaş grupları arasındadır. Araştırmaya katılan bireylerin eğitim durumuna bakıldığında, katılımcıların \% 6,3'ünü lisansüstü, \% 53'üni üniversite, \% 30,5'ini lise, \% 10,3'ünü ilköğretim mezunlarının oluşturduğu görülmektedir. Katılımcılar mesleklerine göre değerlendirildiğinde; \% 12,5'i memur, \% 19,8'i işçi, \% 9'u emekli, \% 24'ü öğrenci, \% 7,5'i ev hanımı, \% 18,3'ü serbest meslek sahibi, \% 5,5'i iş adamı ve \% 3,5'i diğer meslek gruplarındandır. Araştırma örnekleminin aylık ortalama gelir dağılımına bakıldığında, geliri 0-1400 arasında olan katılımcılar \% 10,5'ini, aylık geliri 14002000 arasında olanlar, \% 22,3'ünü, aylık geliri 2201-3500 arasında olan katılımc1lar \% 24,8'ini, aylık geliri 3501-5000 arasında olan katılımcılar \% 28,5'ini ve aylık gelirini 5001 ve üstü olan katılımcılar \%11,8 ini oluşturduğu dikkati çekmektedir.

\subsection{Araştırmanın Sınırlılıkları}

$\mathrm{Bu}$ araştırma 2017 yılının Nisan ayında Ankara ilinin seçilen belli bölgelerindeki ilçelerde yaşayan kişiler ile gerçekleştirilmiştir. Bu doğrultuda araştırma, ankete katılanların verdikleri cevaplar ile sınırlıdır. Bu nedenle ankete verilen cevaplar bu evrenin özellikleri ile sınırlı olduğundan genellemeler yapılırken bu sınırlılık dikkate alınmalıdır

\subsection{Araştırma Bulguları}

Katılımcıların ifadelerinin ortalamaları Tablo-1'de yer almaktadır. 16 Nisan Referandumu ile ilgili bilgi alınan kaynakların oy tercihlerine etkisi ile ilgili soruya verilen cevaplarda, yakın çevreden alınan bilgilere diğerlerinden daha çok güven duyulduğu görülmektedir. En az güven duyulan kaynak olarak Facebook, Twitter, bloglar, forumlar gösterilmiştir. Türkiye'de siyasi bilgi alma alışkanlıklarında birincil yakın ilişkilerin etkili 
olduğu, sosyal medya ve kanaat önderleri gibi ikincil ilişkilerin birincil ilişkilerin ardında kaldı̆̆ı görülmektedir.

16 Nisan Referandumu ile ilgili bilgi alınan kaynakların ne oranda değerli olduğuna ilişkin soruya verilen cevaplara bakıldığında da benzer sonuçlar ortaya çıkmaktadır. Yakın çevreden alınan bilgilerin oranı diğerlerinin çok üzerindedir. Bunu sırasıyla geleneksel medya, internet haber siteleri, sosyal medya ve kanaat önderleri izlemektedir.

İletişim alanındaki etki araştırmalarının ilk dönemlerinden günümüze kadarki süreçte bireysel ve küçük gruplarla yapılan yüz yüze iletişim ve etkileşimin ikna ve tutum oluşturmada etkili olduğu bilinen ve kabul edilen bir görüştür. Bu çalışmada da bu durum açıkça ortaya çıkmaktadır. Güven duyulan ve etkilenilen haber ve bilgi kaynağı olarak yakın çevrenin daha etkili olduğu yapılan alan araştırmasında açıkça görülmektedir. Araştırma verileri haber ve bilgi kaynağı olarak geleneksel medyanın yeni medyadan daha öncelikli olduğunu göstermektedir. Araştırma verilerinin ortaya çıkardığı bir sonuç da iletişim teknolojilerinin gelişmesi, medyaya ulaşmadaki engellerin kalkması, eğitim ve kültür seviyesinin yükselmesi, toplumsal refah düzeyinin artması, bireysel ve kitle iletişim alanını derinden etkileyen yeni medyanın yaygınlaşması ile birlikte kanaat önderlerinin etki düzeyi ve haber ve bilgi kaynağı olma oranın azaldığını ortaya koymasıdır. 


\begin{tabular}{|c|c|c|c|c|c|c|c|}
\hline İfadeler & $\mathbf{N}$ & $\overline{\mathbf{x}}$ & SS & İfadeler & $\mathbf{N}$ & $\overline{\mathbf{x}}$ & SS \\
\hline $\begin{array}{l}\text { Geleneksel medyadan aldığınız } \\
\text { bilgilere } \\
\text { ne oranda güveniyorsunuz? }\end{array}$ & 400 & 4,88 & 2,634 & $\begin{array}{l}\text { Geleneksel medyaya oy tercihinizde } \\
\text { ne kadar etkilidir? }\end{array}$ & 400 & 4,09 & 2,942 \\
\hline $\begin{array}{c}\text { İnternet haber sitelerinden aldığınız } \\
\text { bilgilere ne oranda } \\
\text { güveniyorsunuz? }\end{array}$ & 400 & 4,615 & 2,488 & $\begin{array}{c}\text { İnternet haber siteleri oy tercihinizde } \\
\text { ne kadar etkilidir? }\end{array}$ & 400 & 3,71 & 2,648 \\
\hline $\begin{array}{l}\text { Facebook, Twitter, bloglar, } \\
\text { forumlardan aldığınız bilgilere ne } \\
\text { oranda güveniyorsunuz? }\end{array}$ & 400 & 4,395 & 2,577 & $\begin{array}{l}\text { Facebook, Twitter, bloglar, } \\
\text { forumlardan aldığınız bilgiler oy } \\
\text { tercihinizde ne kadar etkilidir? }\end{array}$ & 400 & 3,567 & 2,689 \\
\hline $\begin{array}{c}\text { Yakın çevrenizden aldığınız } \\
\text { bilgilere ne oranda } \\
\text { güveniyorsunuz? } \\
\end{array}$ & 400 & 6,535 & 2,619 & $\begin{array}{l}\text { Yakın çevrenizden aldığınız bilgiler } \\
\text { oy tercihinizde ne kadar etkilidir? }\end{array}$ & 400 & 5,21 & 2,954 \\
\hline $\begin{array}{c}\begin{array}{c}\text { Kanaat önderlerinden aldığınız } \\
\text { bilgilere ne oranda } \\
\text { güveniyorsunuz? }\end{array} \\
\end{array}$ & 400 & 4,56 & 2,59 & $\begin{array}{c}\text { Kanaat önderlerinden aldığınız } \\
\text { bilgiler oy tercihinizde ne kadar } \\
\text { etkilidir? }\end{array}$ & 400 & 3,632 & 2,59 \\
\hline $\begin{array}{l}\text { Geleneksel medyadan aldığınız } \\
\text { bilgiler ne oranda değerlidir? }\end{array}$ & 400 & 5,377 & 2,493 & $\begin{array}{c}\text { Geleneksel medya referandum } \\
\text { içeriğiyle ilgili sizi ne oranda } \\
\text { bilgilendirdi? } \\
\end{array}$ & 400 & 3,057 & 1,227 \\
\hline $\begin{array}{l}\text { İnternet haber sitelerinden aldığınız } \\
\text { bilgiler ne oranda değerlidir? }\end{array}$ & 400 & 4,88 & 2,466 & $\begin{array}{c}\text { İnternet haber siteleri referandum } \\
\text { içeriğiyle ilgili sizi ne oranda } \\
\text { bilgilendirdi? }\end{array}$ & 400 & 2,992 & 1,14 \\
\hline $\begin{array}{l}\text { Facebook, Twitter, bloglar, } \\
\text { forumlardan aldığınız bilgiler ne } \\
\text { oranda değerlidir? }\end{array}$ & 400 & 4,645 & 2,666 & $\begin{array}{c}\text { Facebook, Twitter, bloglar, forumlar } \\
\text { referandum içeriğiyle ilgili sizi ne } \\
\text { oranda bilgilendirdi? }\end{array}$ & 400 & 2,752 & 1,216 \\
\hline $\begin{array}{l}\text { Yakın çevrenizden aldığınız } \\
\text { bilgilere ne oranda değerlidir? }\end{array}$ & 400 & 6,595 & 2,623 & $\begin{array}{l}\text { Yakın çevreniz referandum içeriğiyle } \\
\text { ilgili sizi ne oranda bilgilendirdi? }\end{array}$ & 400 & 3,157 & 1,243 \\
\hline $\begin{array}{l}\text { Kanaat önderlerinden aldığınız } \\
\text { bilgiler ne oranda değerlidir? }\end{array}$ & 400 & 4,592 & 2,593 & $\begin{array}{l}\text { Kanaat önderleri referandum içeriyle } \\
\text { ilgili sizi ne oranda bilgilendirdi? }\end{array}$ & 400 & 2,495 & 1,27 \\
\hline
\end{tabular}

Yapılan ANOVA testinde (Bkz. Tablo-2), yaş grupları arasında geleneksel medyadan alınan siyasal bilgilere güven duyma durumları arasında anlamlı bir farklılık olduğu ortaya çıkmaktadır. Anlamlı farklılığın hangi gruplar arasında olduğunu belirlemek için yapılan Tukey testinde bu farklılığın 36-45 yaş grupları ile 18-25 yaş grupları arasında olduğu görülmüştür. Buna göre 36-45 yaş grupları arasında yer alanlar 18-25 yaş grupları arasında yer alanlara göre daha fazla geleneksel medyadan aldıkları bilgilere güvenmektedir. 


\begin{tabular}{|c|c|c|c|c|c|}
\hline İfadeler & Yaş Aralığı & $\mathbf{N}$ & $\overline{\mathbf{x}}$ & SS & Test Değeri \\
\hline \multirow{4}{*}{ Geleneksel medya } & 18 - 25 yaş & 132 & 4,560 & 2,577 & \multirow{4}{*}{$\begin{array}{c}F=0,038 \\
p=, 029\end{array}$} \\
\hline & 26 - 35 yaş & 110 & 4,872 & 2,661 & \\
\hline & 36 - 45 yaş & 77 & 5,649 & 2,548 & \\
\hline & 46 - 65 yaş & 81 & 4,670 & 2,673 & \\
\hline \multirow{4}{*}{ İnternet haber siteleri } & 18 - 25 yaş & 132 & 4,750 & 2,400 & \multirow{4}{*}{$\begin{array}{c}F=4,025 \\
p=, 008\end{array}$} \\
\hline & 26 - 35 yaş & 110 & 4,836 & 2,557 & \\
\hline & 36 - 45 yaş & 77 & 4,948 & 2,421 & \\
\hline & 46 - 65 yaş & 81 & 3,777 & 2,459 & \\
\hline \multirow{4}{*}{ Sosyal medya } & 18 - 25 yaş & 132 & 4,613 & 2,375 & \multirow{4}{*}{$\begin{array}{c}\mathrm{F}=\mathbf{3 , 0 0 7} \\
\mathrm{p}=, \mathbf{0 3 0}\end{array}$} \\
\hline & 26 - 35 yaş & 110 & 4,636 & 2,687 & \\
\hline & 36 - 45yaş & 77 & 4,467 & 2,452 & \\
\hline & 46 - 65 yaş & 81 & 3,642 & 2,758 & \\
\hline
\end{tabular}

İnternet haber sitelerinden alınan bilgiler ile yaş grupları arasında anlamlı bir farklılık tespit edilmiştir. Yapılan Tukey testinde bu farklılı̆̆ın 46-65 yaş grupları ile diğer tüm yaş grupları arasında olduğu görülmüştür. Yapılan teste göre 46-65 yaş grupları arasında yer alan katılımcılar, diğer yaş gruplarına kıyasla daha az internet haber sitelerinden aldıkları bilgilere güvendiklerini söylemiştir.

Facebook, Twitter, bloglar, forumlardan alınan bilgiler ile yaş grupları arasında da anlamlı bir farklılık tespit edilmiştir. Yapılan Tukey testinde bu farklılığın 46-65 yaş grupları ile 18-25 ve 26-35 yaş grupları arasında olduğu tespit edilmiştir. Test sonucuna göre 18-25 ve 26-35 yaş grupları arasında yer alan katılımcılar, 46-65 yaş grupları arasında yer alan katılımcılara kıyasla daha az sosyal medyadan aldıkları bilgilere güvendiklerini ifade etmişlerdir. 


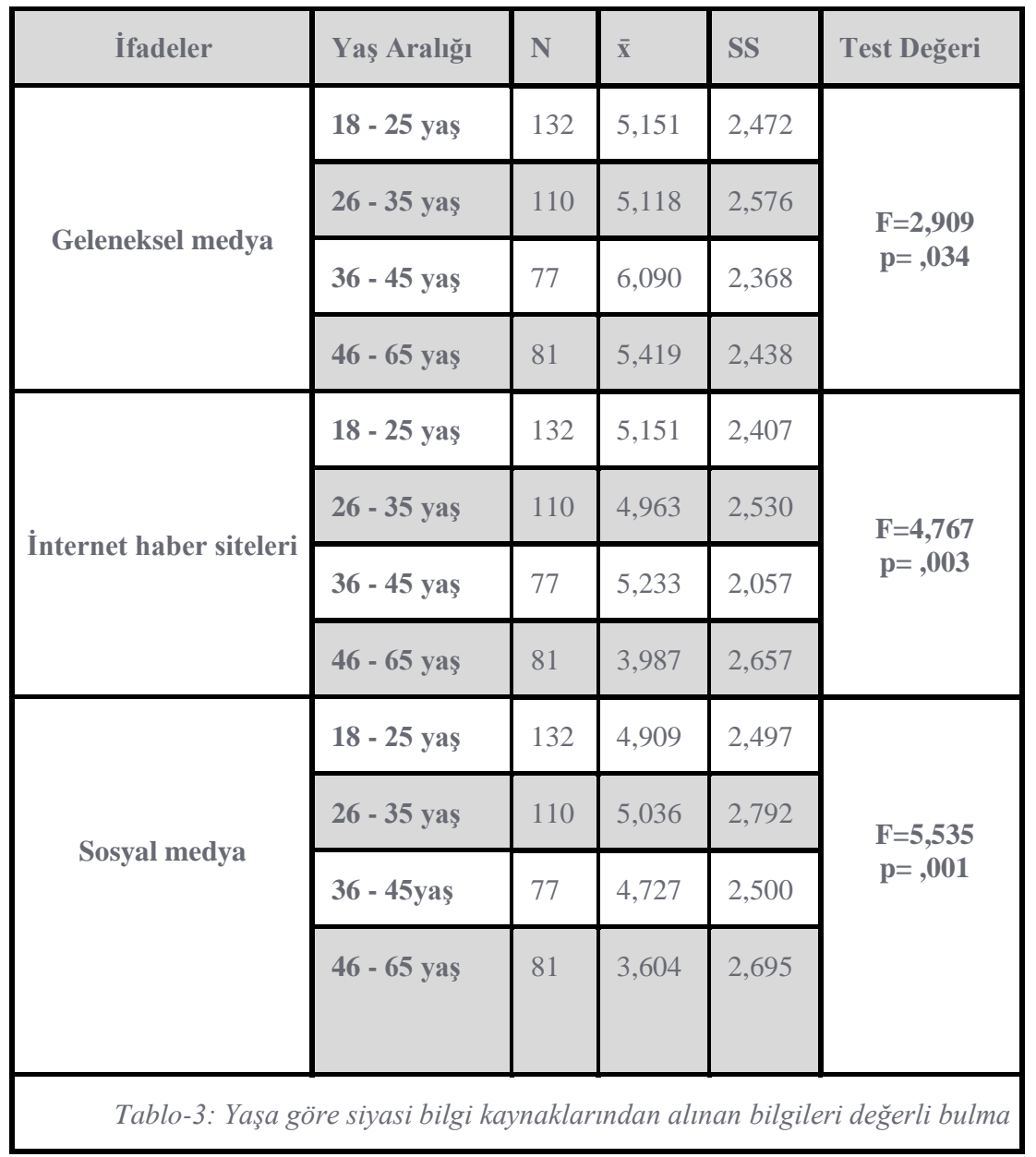

Yapılan ANOVA testinde (Bkz. Tablo-3), geleneksel medyadan alınan bilgileri değerli bulma durumları ile yaş grupları arasında anlamlı bir farklılık tespit edilmiştir. Yapılan Tukey testinde, bu anlamlı farklılığın 36-45 yaş grupları ile 18-25 ve 26-35 yaş grupları arasında olduğu belirlenmiştir. Buna göre 36-45 yaş grupları arasında yer alan katılımcılar, 18-25 ve 2635 yaş gruplarında yer alan katılımcılara kıyasla geleneksel medyadan aldıkları bilgileri daha değerli bulduklarını söylemiştir.

İnternet haber sitelerinden alınan bilgileri değerli bulma ile yaş grupları arasında anlamlı bir farklılık tespit edilmiştir. Yapılan tamhane testinde bu farklılığın 46-65 yaş grupları ile diğer tüm yaş grupları arasında olduğu belirlenmiştir. Yapılan teste göre 46-65 yaş grupları arasında yer alan katılımcılar diğer yaş gruplarına kıyasla internet haber sitelerinden aldıkları bilgileri daha az değerli bulduklarını söylemiştir. 
Facebook, Twitter, bloglar, forumlardan alınan bilgiler ile yaş grupları arasında anlamlı bir farklılık tespit edilmiştir. Bu farklılığın hangi gruplar arasında olduğunu belirlemek için yapılan Tukey testinde, 46-65 yaş grupları arasında yer alan katılımcılar ile diğer tüm yaş grupları arasında anlamlı bir farklılık tespit edilmiştir. Buna göre 46-65 yaş grupları arasında yer alan katılımcılar, diğer yaş gruplarına göre daha az Facebook, Twitter, bloglar, forumlardan aldıkları bilgileri değerli bulduklarını söylemiştir.

\begin{tabular}{|c|c|c|c|c|c|}
\hline İfadeler & Yaş Aralığı & $\mathbf{N}$ & $\overline{\mathbf{x}}$ & SS & Test Değeri \\
\hline \multirow{4}{*}{ Sosyal medya } & 18 - 25 yaş & 132 & 3,598 & 2,534 & \multirow{4}{*}{$\begin{array}{l}F=2,782 \\
p=, 041\end{array}$} \\
\hline & 26 - 35 yaş & 110 & 3,900 & 2,970 & \\
\hline & 36 - 45yaş & 77 & 3,805 & 2,625 & \\
\hline & 46 - 65 yaş & 81 & 2,839 & 2,497 & \\
\hline
\end{tabular}

Yapılan ANOVA testinde (Bkz. Tablo-4), Facebook, Twitter, bloglar, forumlardan alınan bilgilerin oy tercihlerine etkisi ile yaş grupları arasında anlamlı bir farklılık tespit edilmiştir. Bu farklılığın hangi gruplar arasında olduğunu tespit etmek için yapılan Tukey testinde bu farklılığın 46-65 yaş grupları ile 26-35 yaş grupları arasında olduğu tespit edilmiştir. Buna göre 26-35 yaş grupları arasında yer alan katılımcılar, 46-65 yaş grupları arasında yer alan katılımcılara kıyasla daha fazla Facebook, Twitter, bloglar, forumlardan aldıkları bilgilerin oy tercihlerinde etkili olduğunu belirtmiştir.

\begin{tabular}{|c|c|c|c|c|c|}
\hline İfadeler & Eğitim Düzeyi & $\mathbf{N}$ & $\overline{\mathbf{x}}$ & SS & est Değeri \\
\hline \multirow{4}{*}{ Geleneksel medya } & İlköğretim & 41 & 5,756 & 2,736 & \multirow{4}{*}{$\begin{array}{l}F=4,955 \\
p=0,002\end{array}$} \\
\hline & Lise & 122 & 5,352 & 2,769 & \\
\hline & Üniversite & 212 & 4,533 & 2,494 & \\
\hline & Lisansüstü & 25 & 4,080 & 2,325 & \\
\hline \multirow{3}{*}{ Sosyal medya } & İlköğretim & 41 & 3,292 & 2,512 & \multirow{3}{*}{$\begin{array}{l}F=4,770 \\
p=0,003\end{array}$} \\
\hline & Lise & 122 & 4,147 & 2,563 & \\
\hline & Üniversite & 212 & 4,787 & 2,549 & \\
\hline
\end{tabular}




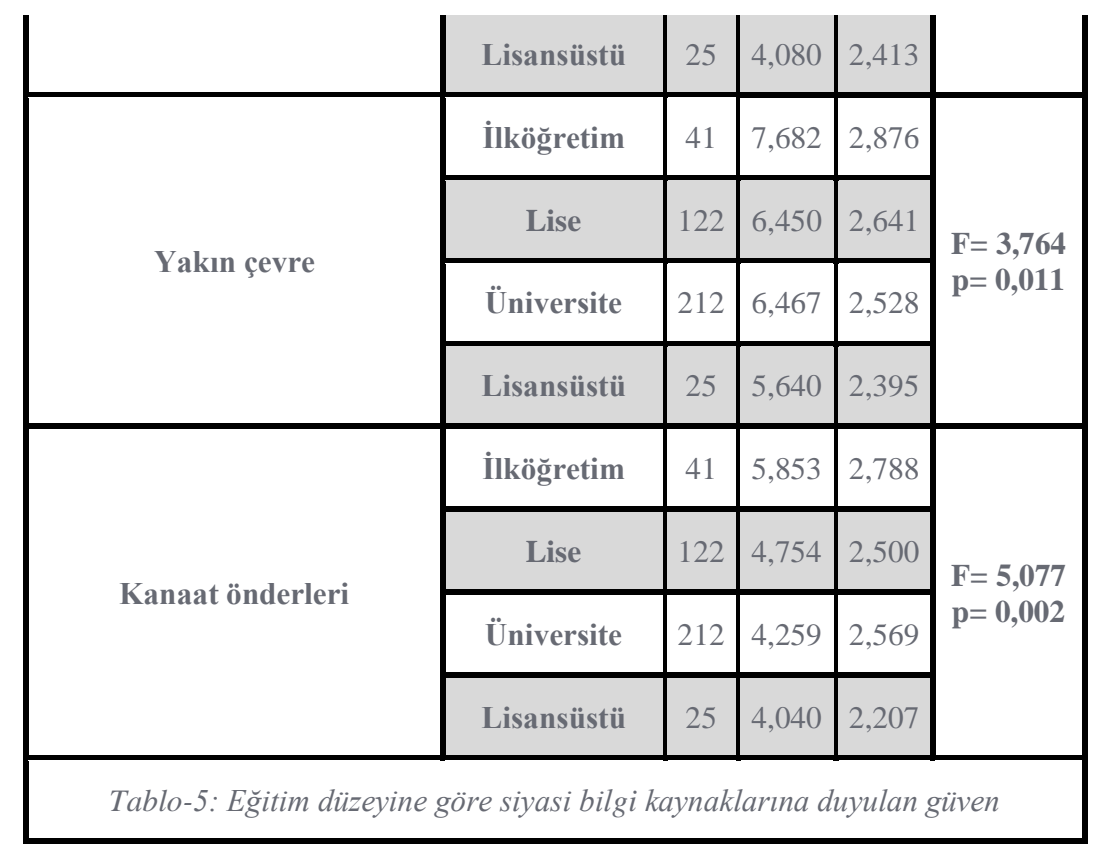

Yapılan ANOVA testinde (Bkz. Tablo-5), geleneksel medyadan alınan bilgilere güven duyma düzeyleri ile eğitim durumları arasında anlamlı bir farklılık tespit edilmiştir. Yapılan Tukey testinde bu anlamlı farklılı̆̆ın üniversite mezunları ile ilköğretim ve lise mezunları arasında olduğu tespit edilmiştir. Buna göre ilköğretim ve lise mezunları, üniversite mezunlarına kıyasla daha fazla geleneksel medyadan aldıkları bilgilere güvenmektedir.

Facebook, Twitter, bloglar, forumlardan alınan bilgilere güvenme düzeyleri ile eğitim durumları arasında anlamlı bir farklılık tespit edilmiştir. Yapılan Tukey testinde anlamlı farklığın üniversite mezunları ile ilköğretim mezunları arasında olduğu belirlenmiştir. Yapılan analize göre üniversite mezunları ilköğretim mezunlarına kıyasla daha fazla Facebook, Twitter, bloglar, forumlardan aldıkları bilgilere güvendiklerini ifade etmiştir.

Yakın çevreden alınan siyasi bilgilere güven ile eğitim düzeyleri arasında anlamlı bir farklılık tespit edilmiştir. Bu farklılığın hangi gruplar arasında olduğunu belirlemek için yapılan Tukey testinde ilköğretim mezunları ile diğer eğitim düzeyleri arasında anlamlı bir farklılık tespit edilmiştir. Yapılan analize göre ilköğretim mezunları diğer eğitim düzeylerine göre daha fazla yakın çevrelerinden aldıkları bilgilere güvendiklerini ifade etmiştir.

Kanaat önderlerinden alınan bilgilere güvenme düzeyleri ile eğitim düzeyleri arasında anlamlı bir farklılık tespit edilmiştir. Bu farklılığın hangi gruplar arasında olduğunu belirlemek için yapılan Tukey testinde, ilköğretim mezunları ile üniversite ve lisansüstü mezunları arasında 
anlamlı bir farklılık tespit edilmiştir. Yapılan analize göre ilköğretim mezunları, üniversite ve lisansüstü mezunlarına kıyasla daha fazla kanaat önderlerinden aldıkları bilgilere güvendiklerini söylemiştir.

\begin{tabular}{|c|c|c|c|c|c|}
\hline Ífadeler & Eğitim Düzeyi & $\mathbf{N}$ & $\overline{\mathrm{x}}$ & SS & Test Değeri \\
\hline \multirow{4}{*}{ Geleneksel medya } & İllköğretim & 41 & 6,536 & 2,608 & \multirow{4}{*}{$\begin{array}{l}F=5,499 \\
p=0,001\end{array}$} \\
\hline & Lise & 122 & 5,631 & 2,546 & \\
\hline & Üniversite & 212 & 5,117 & 2,396 & \\
\hline & Lisansüstü & 25 & 4,440 & 2,161 & \\
\hline \multirow{4}{*}{ Sosyal medya } & İlköğretim & 41 & 3,268 & 2,655 & \multirow{4}{*}{$\begin{array}{l}F=7,012 \\
p=0,000\end{array}$} \\
\hline & Lise & 122 & 4,344 & 2,702 & \\
\hline & Üniversite & 212 & 5,132 & 2,581 & \\
\hline & Lisansüstü & 25 & 4,240 & 2,259 & \\
\hline \multirow{4}{*}{ Kanaat önderleri } & İlköğretim & 41 & 5,804 & 2,830 & \multirow{4}{*}{$\begin{array}{l}F=\mathbf{4 , 8 5 5} \\
p=0,002\end{array}$} \\
\hline & Lise & 122 & 4,803 & 2,664 & \\
\hline & Üniversite & 212 & 4,221 & 2,407 & \\
\hline & Lisansüstü & 25 & 4,720 & 2,791 & \\
\hline
\end{tabular}

Yapılan ANOVA testinde (Bkz. Tablo-6), geleneksel medyadan alınan bilgilerin ne oranda değerli olduğu ile eğitim düzeyleri arasında anlamlı bir farklılık tespit edilmiştir. Yapılan Tukey testinde bu anlamlı farklılığın ilköğretim mezunları ile üniversite ve lisansüstü mezunları arasında olduğu belirlenmiştir. Buna göre ilköğretim mezunları üniversite ve lisansüstü mezunlarına kıyasla geleneksel medyadan aldıkları bilgileri daha değerli bulmaktadır.

Facebook, Twitter, bloglar, forumlardan alınan bilgilerin ne oranda değerli olduğu ile eğitim düzeyleri arasında anlamlı farklılıklar tespit edilmiştir. Yapılan Tukey testinde bu anlamlı farklı1ığın üniversite mezunları ile ilköğretim ve lise mezunları arasında olduğu belirlenmiştir. Buna göre üniversite mezunları Facebook, Twitter, bloglar, forumlardan aldıkları bilgilerin daha değerli olduğunu söylemiştir. 
Kanaat önderlerinden alınan bilgilerin ne oranda değerli olduğu ile eğitim düzeyleri arasında anlamlı bir farklılık tespit edilmiştir. Bu farklılığın hangi gruplar arasında olduğunu belirlemek için yapılan Tukey testinde, ilköğretim mezunları ile üniversite mezunları arasında anlamlı bir farklılık tespit edilmiştir. Buna göre ilköğretim mezunları üniversite mezunlarına kıyasla kanaat önderlerinden aldıkları bilgileri daha değerli bulduklarını söylemişlerdir.

\begin{tabular}{|c|c|c|c|c|c|}
\hline Ífadeler & Eğitim Düzeyi & $\mathbf{N}$ & $\overline{\mathbf{x}}$ & SS & Test Değeri \\
\hline \multirow{4}{*}{ İnternet haber siteleri } & İlköğretim & 41 & 2,512 & 1,120 & \multirow{4}{*}{$\begin{array}{l}F=3,334 \\
p=0,020\end{array}$} \\
\hline & Lise & 122 & 2,950 & 1,112 & \\
\hline & Üniversite & 212 & 3,113 & 1,129 & \\
\hline & Lisansüstü & 25 & 2,960 & 1,240 & \\
\hline \multirow{4}{*}{ Yakın çevre } & İlköğretim & 41 & 3,390 & 1,222 & \multirow{4}{*}{$\begin{array}{l}F=3,631 \\
p=0,013\end{array}$} \\
\hline & Lise & 122 & 3,262 & 1,218 & \\
\hline & Üniversite & 212 & 3,136 & 1,252 & \\
\hline & Lisansüstü & 25 & 2,440 & 1,121 & \\
\hline
\end{tabular}

Yapılan ANOVA testinde (bkz. Tablo-7), internet haber sitelerinden bilgi alma oranları ile eğitim düzeyleri arasında anlamlı bir farklılık tespit edilmiştir. Bu anlamlı farklılığın hangi gruplar arasında olduğunu belirlemek için yapılan Tukey testinde, üniversite mezunları ile ilköğretim mezunları arasında anlamlı bir farklılık tespit edilmiştir. Buna göre üniversite mezunları, ilköğretim mezunlarına kıyasla daha fazla internet haber sitelerinden siyasi bilgi almakta olduklarını söylemiştir.

Yakın çevreden siyasi bilgi alma oranları ile eğitim düzeyleri arasında anlamlı farklılıklar tespit edilmiştir. Bu farklılıkların hangi gruplar arasında olduğunu belirlemek için yapılan Tukey testinde, lisansüstü mezunları, diğer eğitim düzeyleri kıyasla daha az yakın çevrelerinden siyasi konular hakkında bilgi edindiklerini söylemiştir. 


\section{SONUÇ}

Seçmen davranışları ve kişilerin oy tercihlerinde etki eden faktörlerin neler olduğunun belirlenmesi her zaman merak uyandıran konular arasında olmuştur. Günümüzde yeni medya araçları ile birlikte siyasi bilgi alma kanalları çeşitlenmiş, kişilere farklı kanallardan ulaşma imkânı sağlanmıştır. Günümüzün artan iletişim olanaklarında seçmenlerin hangi kaynaklardan bilgi aldıkları, hangi kaynaklara güvendikleri ve hangi kaynaklardan etkilendikleri merak edilmektedir. Kitle iletişim araçlarının kısıtlı olduğu dönemlerde aktif rol oynayan kanaat önderlerinin günümüz iletişism ortamlarında nasıl bir rol oynadığı, medyanın mı yoksa kişilerarası ilişkilerin mi etkili olduğunu belirlemek için yapılan bu çalışma, kitle iletişim araçlarının gelişmesi ve yaygınlaşmasına rağmen bireylerin siyasal bilgi kaynağı olarak öncelikle yakın çevrelerine güven duyduğunu göstermektedir.

Çalışmada araştırılan hangi bilgi kaynaklarının ne oranda değerli olduğuna ilişkin verilere bakıldığında da yakın çevreden alınan bilgilerin ortalamanın üzerinde yer aldığı göze çarpmaktadır. Yakın çevreden alınan bilgiler geleneksel ve yeni medya ile kanaat önderlerinden daha değerli bulunmakta, yeni medya ve kanaat önderleri geleneksel medyanın da arkasında yer almaktadır. Bu çerçevede yakın çevrenin siyasal tercihlerini belirlemede de geleneksel ve yeni medya ile kanaat önderlerinden daha fazla etkili olduğu araştırma verilerinin ortaya koyduğu bir sonuç olarak karşımıza çıkmaktadır. Araştırma verileri siyasal bilgi kaynağı olarak birincil yakın ilişkilerin daha etkili olduğunu göstermektedir.

Siyasal bilgi alma kaynakları ve bu kaynaklara atfedilen önem ile siyasal kanaat oluşturmada tercih edilen kaynaklarla ilgili veriler katılımcıların sosyo-demografik ve sosyokültürel özelliklerine göre değerlendirildiğinde farklı bulgulara ulaşılmıştır. Bu çerçevede; 3645 yaş grubunda yer alanların geleneksel medyaya daha fazla, internet haber siteleri ve sosyal medyadan aldıkları bilgilere daha az güvendikleri, geleneksel medyadan aldıkları bilgileri daha değerli buldukları gözlenmiştir. Buna karşılık, 46-65 yaş grubundakilerin diğer yaş gruplarına oranla internet haber sitelerinden ve sosyal medyadan aldıkları bilgileri daha az değerli buldukları belirlenmiştir. Genç yetişkinlerin (26-35 yaş) diğer yaş gruplarına oranla oy tercihlerinde daha fazla sosyal medyadan etkilendikleri araştırmanın sonuçlarındandır.

Araştırma verileri ile ilköğretim mezunları geleneksel medyadan aldıkları bilgileri daha değerli bulurken, üniversite ve lisansüstü mezunlarının sosyal medyadan aldıkları bilgileri daha 
değerli buldukları ortaya konulmuştur. Bu durum sosyal medyada yer alan kanaat önderlerini akla getirmekte, üniversite ve lisansüstü mezunlarının muhtemelen sosyal medyada yer alan birincil ve ikincil ilişkilerden kanaat önderlerini takip ettiklerini düşündürmektedir. Üniversite mezunlarının daha çok internet haber sitelerinden haber alırken, ilköğretim mezunlarının yakın çevrelerinden siyasi bilgi edindikleri sonucuna ulaşılmıştır. Bu durum Türkiye'de kanaat önderlerinin varlığını sürdürmekle birlikte eğitim düzeylerinin artmasıyla kişilerin sosyal medyadan ve diğer yeni medya araçlarından faydalandıkları eğitimli kişilerin daha çok bu kaynaklardan bilgi aldıklarına işaret etmektedir.

Kuşkusuz bu çalışmanın konusunu oluşturan siyasi bilgi kaynakları, siyasi bilgi kaynaklarına güven ve oy tercihine etki eden faktörlerle ilgili farklı zamanlarda ve farklı örneklem grupları ile yapılacak yeni çalışmalar zaman ve örneklem faktörüne göre sonuçların nasıl değiştiğini ortaya koyacak, kanaat önderleri konusunda literatüre katk1 sağlayacaktır.

\section{EXTENDED ABSTRACT}

Today, new media tools and political information channels have diversified and people have been given the opportunity to access information through different channels. Radio, television, newspapers, magazines, etc. unlike traditional media, the level and rate of dissemination of news and information has increased significantly through social networks that come into play with the new media as a part of it. In today's increasing communication opportunities, it is wondered from which sources voters receive information, which sources they trust and from which sources they are affected. In years when media opportunities were more limited, opinion leaders served as bridges between the media and voters. With the communication technologies that are developing today, people can access different information through many channels at the same time. But evolving political information search channels can make it harder for voters to rely on which sources of information. While the Internet offers many different channels for people to access useful information, on the other hand, internet users can be affected by excessive information pollution problems in the new media environment. Many provocative or disinformational content is likely to be encountered on social media. In this mess of information pollution, people may experience uncertainty about what resources to rely on. In order to be affected by media content, it is important that people 
find the source reliable. (Güz, 2005, s. 57, Stroud and Lee, 2013, s. 85). Determining which political information source voters trust more has an important place in determining the media tools that will determine political behavior. The subject of this study is the confidence and opinion leaders in the increasing political information sources in the new media age. The aim at this study is to determine the sources of information that voters prefer in new media environments. The reliance on these sources is to investigate the levels of influence of political information sources on voting preferences. Research data was collected from Ankara province. By random sampling, 15 days before the April 16, 2017 referendum, participants were interviewed face-to-face and answered questions.

The first field research on the topic of opinion leaders was conducted in the United States. But the use of the concept of opinion leaders in Turkey is different from the United States. Because of this difference, in the planned field research, mother, father, friend, etc. the individuals were referred to as the" immediate circle". Loved ones such as the president of the association and teachers were considered "opinion leaders". Participants were asked questions about traditional media, internet news sites, social media (Facebook, Twitter, blog and forums), their level of getting information from close circles and opinion leaders, sources of information they find valuable, and sources of information that they are affected by their political choices. Descriptive statistics were used in the study, and ANOVA test was used to obtain deeper results according to the socio-demographic, socio-economic and socio-cultural characteristics of the participants. As a result of the study, it shows that despite the development and spread of mass media, individuals primarily trust their immediate circle as a source of political information. Information received from the immediate circle is more valuable than traditional media and new media and opinion leaders. New media and opinion leaders are also behind traditional media. As a result of research data, the immediate circle is more effective in determining political preferences than traditional and new media and opinion leaders. Research data show that primary close relationships as a source of political information are more effective. Different findings were reached when the data on the sources of political information and the importance attributed to these sources and the sources preferred in forming political opinion were evaluated according to the socio-demographic and socio-cultural characteristics of the participants. It has been observed that those in the 36-45 age group rely more on traditional media, less on the information they receive from internet news sites and social media, and more on the information 
they receive from traditional media. It has been determined that those in the 46-65 age group find the information they receive from internet news sites and social media less valuable than other age groups. It is one of the results of the study that young adults (26-35 years old) are more influenced by social media in their voting preferences than other age groups. Research data showed that primary school graduates find the information they receive from traditional media more valuable, while University and graduate graduates find the information they receive from social media more valuable. This finding brings to mind opinion leaders on social media, suggesting that university and graduate graduates probably follow opinion leaders from primary and secondary relationships on social media. It has been concluded that while university graduates receive more news from internet news sites, primary school graduates receive political information from their immediate environment. These findings indicate that while opinion leaders continue to exist in Turkey, with increased levels of Education, educated people who use social media and other New Media tools are more likely to receive information from these sources. New studies on political information sources, factors affecting confidence in political information sources and voting preferences, which are undoubtedly the subject of this study, at different times and with different sample groups, will contribute to the literature on how results change over time and sample factors. On the other hand, Turkey's social structure and social relations differ from the United States and Western countries. For this reason, the findings have been interpreted by taking into account Turkey's unique dynamics.

\section{KAYNAKÇA}

Aslan, A. \& Ünlü, D. G. (2016). Instagram fenomenleri ve reklam İlişkisi: Instagram fenomenlerinin gözünden bir değerlendirme. Maltepe Üniversitesi İletişim Fakültesi Dergisi, 3(2), 41-65. Erişim adresi:https://dergipark.org.tr/en/download/articlefile/304423

Balcı, Ş., Damlapınar, Z., Pınarbaşı, T. E. \& Astam, F. K. (2016). Siyasal bilgilenmede medyanın rolü ve etkinliği: Üniversite öğrencileri araştırması. International Journal of Social Science, (53), 111-125. doi:https://doi.org/10.9761/JASSS4870

Bargh, J. A. \& McKenna, K. Y. (2004). The internet and social life. Annu Rev Psychol, 55, 573590. doi:10.11.46/annurev.psych.55.090902.141922. 
Berelson, B., Gaudet, H. \& Lazarfeld, F. P. (1944). The people's choice: How the voter makes up his mind in a presidential campaign. New York, NY: Duell, Sloan, and Pearce.

Bimber, B. (1998). The internet and political transformation: Populism, community, and Accelerated Pluralism. Polity,31(1), 133-160. doi:10.2307/3235370

Büyükaslan, A.\& Kınık, M. A. (2017). Genel iletişim, sosyal medya ve sanat pazarı,. A. Büyükaslan \& M. A. Kınık (Yay. haz). Sosyalleşen birey sosyal medya araştırmaları 1 içinde (s.253-284). Konya: Çizgi Kitapevi.

Castells, M. \& Ince, M. (2006). Manuel Castells'le söyleşiler. (E. K. Çakmak, Çev). İstanbul Bilgi Üniversitesi Yayınları.

Demirtaş, Z. G. (2019a, Aralık). Geleneksel medyadan yeni medyaya kamuoyu/kanaat önderleri (Yayımlanmamış doktora tezi). Gazi Üniversitesi Sosyal Bilimler Enstitüsü, Ankara.

Demirtaş, Z. G. (2019b). Dijital çağda influencer olarak instagram anneleri. H. Akgül, E. Eke (Yay. haz). Dijital çocuk ve ebeveyler, dijital nesillerin teknoloji bă̆ımlılı̆̆ı içinde (s. 177-204). Ankara: Nobel Yayınları.

Dijk, V. J. (2018). A ̆g toplumu. (Ö. Sakin, Çev.) İstanbul: Kafka Yayınları.

Geray, H. (2003). Illetişim ve teknoloji: Uluslararası birikim düzeninde yeni medya politikaları. Ankara: Ütopya Yayınevi.

Gündüz, U. \& Pembecioğlu, N. (2013). Bilgi kaynağı olarak sosyal ağlar ve sosyal medya. M. Demir (Yay. haz). Yeni medya üzerine. Yeni iletişim teknolojileri içinde (s. 311-338). Konya: Literatürk.

Güz, N. (2005). Haberde yönlendirme ve kamuoyu araştırmalarl (1. b.). Ankara: Nobel Yayınevi.

Güz, N. (2018). News transformation from traditional media and new media. N. Güz \& C. Yegen (Yay. haz). Media with its news, approaches and fractions in the new media age içinde (s.17-40). Berling, Germany: Peter Lang. 
Güz, N. \& Demirtaş, Z. G. (2019). Yeni medya çağında siyasi konuşma ve kanaat önderliği: 24 Haziran Cumhurbaşkanlığı Seçimi örneği. Yeni Medya,(7), 1-19. Erişim adresi:https://dergipark.org.tr/en/pub/yenimedya/issue/56886/798645

Güz, N. \& Yeğen, C. (2019). Sosyal medyada kanaat önderliği ve Spor Bilimleri Fakültesi öğrencileri: Futbol özelinde bir değerlendirme, D. A. Arslan, M. Akhan \& M. Mirov (Dü.), 3. Uluslararası Akdeniz Sempozyumu Bildiri Tam Metinleri Kitabı 2. içinde (s.242-260). Mersin: Ak Yayınları.

Huckfeldt, R. R. \& Sprague, J. (1995). Citizen, politics and social communication, information. Newyork, NY, USA: Cambrige University Press.

Huckfeldt, R., Johnson, P. E. \& Sprague, J. (2004). Political disagreement. New York, NY: Cambridge University Press.

Hwang, Y. (2015). Does opinion leadership increase the followers on Twitter. International Journal of Social Science and Humanity, 5(3), 258-264. doi: 10.7763/IJSSH.2015.V5.464

Johnson, T. J. \& Kaye, B. K. (2004). Wag the blog: How reliance on traditional media and the trust the internet influence credibility perceptions of weblogs among blog users. Journalism \&amp; Mass Communicaiton Quarterly, 83(1), 622-644. doi:https://doi.org/10.1177/107769900408100310

Katz, E. \& Lazarfeld, P. F. (1955). Personal influence (2. b.). New Jersey: Transaction.

Kushin, M. J. \& Yamamoto, M. (2010). Did social media really matter? College students' use of online media and political decision making in the 2008 election. Mass $\begin{array}{lll}\text { Communication } \quad \text { and } & \text { 622-624. }\end{array}$ doi:https://doi.org/10.1080/15205436.2010.516863

Ladd, M. J. (2010). The role of media distrust in partisan voting. Polit Behav, 32(4), 567-585. doi:10.1007/s11109-010-9123-Z

Lin, T.-B., Li, J.-Y., Deng, F. \& Lee, L. (2013). Understanding new media literacy: Anexplorative theoretical framework. Educational Technology \& Society, 16(4), 160170.

Erişim 
adresi:https://www.jstor.org/stable/jeductechsoci.16.4.160?seq=1\#metadata_info_tab_ contents

Manovich, L. (2001). The language of new media. New York, NY,USA: The MIT Press

McMillan, J. S. (2006). Eploring models of interactivity from multiple research traditions: Users, documents and systems. A. Lievrouv \& S. Livingstone (Yay.haz). Handbook of new media: Social shaping and social consequences of ICTs leah içinde (s. 205-299). London, UK: Sage Publications.

Mutz, D. C. \& Young, L. (2011). Communicaiton and public opinion plus ça change. Public Opinion Quarterly, 75(5), 1018-1044. doi:https://doi.org/10.1093/poq/nfr052

Newman, N., Fletcher, R., Levy, D. A. \& Nielsen, R. K. (2016). Reuters institute digital. Erişim adresi:http://media.digitalnewsreport.org/wp-content/uploads/2018/11/Digital-NewsReport-2016.pdf?x89475

Olkun, E. O., Yüksel, E. \& Akdemir, G. Y. (2018). Sosyal medya ve siyasal katılım:2017. Uluslararası Sosyal Araştırmalar Dergisi, 11(60), 992-100. doi:10.17719/jisr.2018.2850

Pavlik, J. (1998). New media technology: Cultural and commercial perspectives. Boston, USA: Allyn and Bacon.

Peng, T.-Q., Liu, M., Wu, Y. \& Liu, S. (2016). Follower-followee network, communication networks and vote agreement of U.S. Communication Research, 43(7). doi:https://doi.org/10.1177/0093650214559601

Schäfer, M. S. \& Taddicken, M. (2015). Mediatized opinion leaders: New patterns of opinion leadership in new media environments? International Journal of Communication, 9,960-981. Erişim adresi:https://ijoc.org/index.php/ijoc/article/view/2778

Shah, D. V., Cho, J., Eveland, W. P. \& Kwak, N. (2005). Information and expression in a digital age: Modeling internet effects on civic participation. Communication Research, 32(5), 531-565. doi: 10.1177/0093650205279209

Shah, D., Schmierbach, M. G., Hawkins, J., Espino, R. \& Donavan, J. (2005). Nonrecursive models of internet use and community engagement: Questioning whether time spent 
online erodes social capital. Journalism \&amp; Mass Communication Quarterly, 79(4). doi:https://doi.org/10.1177/0093650205279209

Shearer, E. (2018). Social media outpaces print newspapers in the U.S. as a news source. Pew Recearch Center: Erişim adresi:https://www.pewresearch.org/fact$\operatorname{tank} / 2018 / 12 / 10 /$ social-media-outpaces-print-newspapers-in-the-u-s-as-a-news-source/

Shirky, C. (2010). Herkes örgüt- internet gruplarının gücü. (P. Giraz, Çev.) İstanbul: Optimist Yayın Dağıtım.

Stroud, N. J. \& Lee, J. K. (2013). Perception of calbe news credibility. Mass Communication and Society, 16(1), 67-88. doi:10.1080/15205436.2011.646449

Tailor, M. \& Perry, C. D. (2005). Diffusion of traditional and new media tactics in crisis communication. Public Relations Review, 31(2), 209-217. doi:https://doi.org/10.1016/j.pubrev.2005.02.018

Ulutaş, E. (2015). Toplumsal bir tip: Kanaat önderi (Yayımlanmamış doktora tezi). Selçuk Üniversitesi, Sosyal Bilimler Enstitüsü, Konya.

Wang, Y. (2017). Review for 1dentifying online opinion leaders. World Academy of Science,Engineering and Technology International Journal of Economics and Management, 11(10), 2519-2523. doi:10.5281/zenodo.1314506

Weiman, G. (1994). The influentials:People who influence people. Newyork, NY: State University of New York Press.

Yıldızgörür, M. R. (2018, Haziran). Sosyal medya güvenirlik algısının bilgi paylaşma davranışıla ilişkisi: Anadolu üniversitesi öğrencileri örneği (Yayımlanmamış doktora tezi). Anadolu Üniversitesi Sosyal Bilimler Enstitüsü,Eskişehir. 